\title{
Personal DNA sequence modification: a potential new modality for gene transmission and therapy as well as mammalians evolution.
}

Khaled M.E Elawdan ( $\square$ Elawdan1@shefaaresearch.com )

Youssof K Elawdan

College of medicine, 6 October University

Ezzat A. Eldrieny

Tanta University Faculty of Medicine

Mohammed B. Samy

Beni Suef University Faculty of Veterinary Medicine

Research note

Keywords: Foster mother, gene therapy, breast feeding, DNA sequence change

Posted Date: July 2nd, 2019

DOI: https://doi.org/10.21203/rs.2.10808/v1

License: (c) (1) This work is licensed under a Creative Commons Attribution 4.0 International License.

Read Full License 


\section{Abstract}

Objective: Changes in DNA sequence are usually caused by viruses, certain chemicals and radiation as well as by transposons, somatic hyper mutation and errors during meiosis. We can consider gene therapy as an induced DNA sequence changes by inserting certain gene or genes, through viral vectors mainly. Anyhow, many problems met gene therapy like short-lived nature, need for multiple rounds of that therapy, immune response for gene or vector as foreigners, problems with viral vectors and malignancy induction. Wet nurse or foster suckling mother means breastfeeding an infant that is not one's biological offspring which was a job from ancient Egyptians times till the present. Results: Here we show a significant change in DNA sequence in babies after foster mothers suckling compared to their DNA before suckling foster mother suggesting presence of potential factors in foster mother milk which can change DNA sequence in babies before weaning. This may open the door to study milk as a new potential method for gene transmission and therapy. A method, that probably overcome many of problems meeting gene therapy as well as a possible cause for evolution in mammalians if we consider cross nursing during milk feeding from other species before weaning.

\section{Introduction}

Personal DNA sequence is unique and assumed to be stable all over his or her life span except in some cases of mutation or modification due to endogenous or exogenous factors exposures. Exogenous factors caused mutations include ultraviolet of sunshine, ionizing radiation, mutagenic chemicals and viruses. Endogenous factors include transposons and errors during meiosis process [1, 2, 3].

It is estimated as many as one million individual molecular lesions per cell per day could be found. This constitutes only $\mathbf{0 . 0 0 0 1 6 5 \%}$ of the human genome's (approximately 6 billion bases) and some of these lesions may lead to some sort of mutation[4].In addition those DNA sequence changes could also be induced in gene therapy by inserting certain gene or genes using viral vectors mainly or non-viral method to treat certain disease [5].

Anyhow, many problems met gene therapy like short-lived nature of gene therapy and need for multiple rounds of that therapy, immune response for gene or vector as foreigners, problems with viral vectors and malignancy induction $[6,7,8]$.

Wet nurse or a foster suckling mother means breastfeeding an infant that is not one's biological offspring's which was well known as a job from ancient Egyptians times to the present [9]. Breast feeding either from biological mother or wet nurse is contraindicated in case of active tuberculosis or aids [10].Shared breast feeding identified as new risk factor in aids[11].So, wet nurse should be healthy, well-nourished, non-smoker and non- alcoholic. She should be also screened for tuberculosis, syphilis, hepatitis-associated antigen, cytomegalovirus, herpes virus, HIV and other infectious agents. Also her biological infant should be healthy, gaining well and free of all infections. 
A new relation after foster mother suckling was also found in some holly books that prohibits marriage between the sucker and the suckled and between near relatives of the suckled and the sucker just like real relatives [9].The possible therapeutic potential of factors in human milk was also postulated to treat intestinal immaturity in neonates [12]. Mammary stem cells were also identified in human breast milk [13].

\section{Proposal}

Milk from foster mothers may change DNA sequence in babies before weaning and this may open the door for further studies as alternative methods for gene therapy in hereditary diseases in babies before weaning as well as possible factor in mammalians evolution.

Pilot Data:

Here we show significant changes of personal DNA sequence after milk feeding by a selective suckling foster mother which suggests a new potential method for gene transmission and therapy that most probably overcome many problems meeting gene therapy $[14,15]$.

Methods:

Two groups each consists of three babies exclusively breast feeding, one to two month age, without any type of consanguinity.

Group 1:

It consists of one male and two female babies. Informed Consents were obtained from parents after IRB approval to get four buccal samples for DNA analysis from each baby.

All babies and their mothers were healthy with no possibility of infectious diseases.

First buccal swab was taken from each baby for complete DNA scan analysis by decodme genetics, Ltd. Sturlugata 8, IS-101 Reykjavik, Iceland.

Cross nursing was done. Thus, the mother of first baby was asked to give her baby for the mother of second baby for few hours per day to have 3-5 times of suckling per day for a duration of 2 weeks i.e to be as a foster suckling mother for first baby.

The same maneuver was done for second and third baby. It is clear that during that duration of 2 weeks, the rest of feeding for every baby was done by his or her biological mother milk feeding.

For further clarification, the second baby mother became a foster suckling mother for the first baby, the third baby mother became a foster suckling mother for the second baby and the first baby mother became a foster suckling mother for the third baby. 
Second buccal swab was taken from each baby for complete DNA scan analysis by the same company.

Another cycle of (cross nursing) for the same duration of 2 weeks and same times of suckling per day by making the second baby mother as a foster suckling mother for third baby, the third baby mother as a foster mother for first baby and the first baby mother as a foster suckling mother for the second baby.

Third buccal swab was taken again from each baby for DNA analysis by the same firm.

After finishing the second cycle, each baby relied upon his or her own biological mother milk feeding and around the age of 6 months additional suitable food may be added before the last samples.

Around the ages of 6 month, fourth buccal swab was taken from each baby only to confirm any possible sustained changes.

Group 2:

It consists of two males and one female. It is the control group.

We had a first buccal swab for DNA analysis from each baby. Then after one month and 6 months of his or her own biological mother exclusively breast feeding, the second DNA buccal swab was taken.

\section{Results}

For the first baby, in figure S4 apparent change in genetic sharing of 2nd sample after first foster mother suckling compared to $1^{\text {st }}$ sample before it.

No change could be found in figure $S 5$ in genetic sharing of 3rd sample after second foster mother suckling compared to $1^{\text {st }}$ sample.

Again in figure S6 genetic sharing changes was found in 4th sample at the age of 6 month compared to $1^{\text {st }}$ sample.

For second baby, as shown in figure S1 apparent changes in genetic sharing in 2nd sample after first foster mother suckling compared to 1 st sample.

Also changes could be found in figure $\mathrm{S} 2$ in genetic sharing of 3rd sample after second foster mother suckling compared to $1^{\text {st }}$ sample.

Also in figure S3 genetic sharing changes was found of 4th sample at the age of 6 month compared to $1^{\text {st }}$ sample. 
For the third baby, unfortunately, second sample was of low DNA content unfit for analysis and we couldn't get it again because of the start of the second cycle of foster suckling mothers.

Thus, our data was only for $3^{\text {rd }}$ and $4^{\text {th }}$ samples as in figure S7 apparent changes in genetic sharing of 3rd sample after second foster mother suckling compared to 1 st sample.

Also in figure S8 genetic sharing changes were found of 4th sample at the age of 6 month compared to $1^{\text {st }}$ sample. Maximum fragment size was used to see shared chromosome fragments from very recent common ancestors.

Based on a fragment size of 250 kilo base $(\mathrm{Kb})$ - 20 million base (Mb), calculated in the same way as in the Genetic Atlas but with different fragment size and number of comparisons. Genetic sharing of first baby's $2^{\text {nd }}, 3$ rd and $4^{\text {th }}$ sample after foster suckling mothers compared to $1^{\text {st }}$ sample before foster suckling mother was identified as in table no: 1.

The same happened with second baby's $2^{\text {nd }}, 3 r d$ and $4^{\text {th }}$ sample after foster suckling mothers compared to $1^{\text {st }}$ sample before foster suckling mother as in table no:2

For third baby only genetic sharing in $3^{\text {rd }}$ and $4^{\text {th }}$ sample after foster suckling mothers compared to $1^{\text {st }}$ sample before foster suckling mother which was identified as in table no: 3 .

For control group, genetic sharing of first, second and third control babies' 2 nd samples with their $1^{\text {st }}$ samples was investigated as in table no: S1.

A comparative study was hold between the first baby genetic sharing changes of mean value of $2 n d$ \& 3rd samples after foster mothers suckling and his 1 st sample and, mean value of control DNA changes of 2ndsamples (of all control babies) to 1st samples (of all control). It showed a high significant difference in low DNA sharing (no copy match) using t.test with $P$ value: 0.001 and for medium DNA sharing (only one copy match) $P$ value: 0.002 but with no significant $P$ value for high DNA sharing (two copy match).

A comparative study of the second baby genetic sharing changes of mean value of 2 nd \& 3 rd samples after foster mothers suckling to his 1 st sample compared to mean value of control DNA changes of $2^{\text {nd }}$ samples to 1st samples, showed a high significant difference in low DNA sharing (no copy match) $P$ value:0.001 and for medium DNA sharing( only one copy match) $P$ value:0.001 but with no significant $P$ value for high DNA sharing ( two copy match).

For the third baby, second sample of low DNA content was unfit for analysis. 
A comparative study of the third baby DNA sequence changes of 3rd sample after foster mothers suckling to his 1 stsample, compared to mean value of control DNA changes of 2 nd samples to $1 \mathrm{st}$ samples, showed a high significant difference in low DNA sharing (no copy match) P value:0.001 and also for medium DNA sharing( only one copy match) $P$ value:0.001 but with no significant $P$ value for high DNA sharing ( two copy match).

High significant sequence changes were found in only low and medium DNA sharing of first baby's 4th sample (6 month age) compared to 2 nd and to 3rd samples of the same baby, $p$ value: $0.001,0.001$, 0.001 respectively and also high significant sequence changes occurred in only low and medium DNA sharing of second baby's 4th sample (6 month age) compared to 2nd and to 3rdsamples of the same baby with $P: 0.001,0.049,0.014,0.017$ respectively.

Again high significant sequence changes took place in only low and medium DNA sharing of third baby 4th sample (6 month age) compared to 3rd sample of the same baby :0.001,0.001 respectively.

\section{Discussion}

For my knowledge, this is the first complete scan study of the effect of foster mother milk in human genetics. Decode genetics, Ltd. as a firm analyses about one million Single Nucleotide Polymorphism (SNPs) for complete scan samples.

Many researches used foster pups in mice.

Van der veen $\mathrm{R}$, et al studied the impact of intra- and interstrain cross-fostering on mouse maternal care which demonstrates that both mother strain and pup strain are key determinants of maternal behavior [16].

Another study suggests fostering pup within 24 hours of birth from Helicobacter hepaticas- free mothers to get Helicobacter- free mouse colonies [17].

Improvement in mouse maternal care imposed by replacing biological EL dams with foster CD-1 mothers was sufficient to decrease pup mortality, increase body weight gain $(+0.1 \mathrm{~g} /$ day $)$ and delay the onset of seizure susceptibility in EL offspring beyond post-natal day 80-90 [18].

The entire mice genome was scanned to search for quantitative trait loci whose effects depend on crossfostering and detected 10 of such loci. Of the 10 loci, 4 showed imprinting by cross-foster interactions. In most cases, the interaction effect was due to the presence of an effect in either cross-fostered or noncross-fostered animals.

Genomic imprinting effects may often be modified in mice by the maternal environment and that such interactions can impact key fitness-related traits suggesting a greater plasticity of genomic imprinting than previously assumed [19]. 
Early-life stress of cross-fostering in mice induced long-lasting emotional abnormalities, which might be possibly related to alterations of serotonin metabolisms [20].

As regard celiac disease, our study showed increase in risk factor in second baby (male) $2^{\text {nd }}$ sample after first foster mother (0.22) compared to his $1^{\text {st }}$ sample before foster mothers $(0.17)$.

Surprisingly, this risk factor returned to 0.17 in his $3^{\text {rd }}$ sample after second foster mother and also in his $4^{\text {th }}$ sample at the age of 6 month suggesting high genome plasticity or repair.

A new study suggest clinical evaluation weighing the pros and cons of nursing male versus female children by mothers with genetically-linked hypersensitivity diseases, such as celiac disease and eczema, or those in regions of the world with endemic DTH-eliciting diseases, such as tuberculosis [21].

\section{Limitations}

Some limits are taken into account: number of participating babies in the study is small and a further study must be done to confirm the results. Decodme company where DNA analysis was done is collapsed nowadays and stopped its activities.

\section{Declerations}

\section{Acknowledgements}

I hope to thank Mrs. Gehan Rifaat, Mrs. Hend Elawdan and Dr.Ahmed Abo Alaz for their help and encourage.

Many great thanks for Mrs. Yomna Elawdan for her help in English check.

I also thank all mothers \& fathers of all shared babies for their cooperation that I think truly, without that cooperation, this project is nil.

Thanks for Mr.Esam El-Ghor for his help in statistics.

\section{Funding}

There is no specific funding to declare.

\section{Authors' contributions}

Conception and design: K M.E E. Development of methodology: K M.E E. Writing, review, and/or revision of the manuscript: K M.E E, Y K E, E A E \& M B S. Study supervision: K M.E E. All authors approved the 
final manuscript.

\section{ETHICS APPROVAL AND CONSENT TO PARTICIPATE}

Informed Consents were obtained from parents after IRB approval of shefaa City Hospital to get four buccal samples for DNA analysis from each baby.

\section{Consent for publication}

Not applicable.

\section{Availability of data and materials}

decodme genetics, Ltd. Sturlugata 8, IS-101 Reykjavik, Iceland was the company where all DNA analysis studies were done as a paid service.

\section{Competing interests}

no competing interests.

\section{References}

1. Aminetzach, Y.T., Macpherson, J.M., and Petrov D.A. 2005, Pesticide resistance via transpositionmediated adaptive gene truncation in Drosophila. Science, 309, 764-767

2. Burrus, V.and Waldor, M. 2004, Shaping bacterial genomes with integrative and conjugative elements. Res. Microbiol.,155, 376-86

3. Bertram, J. 2000, The molecular biology of cancer. Mol. Aspects Med.,21,167-223

4. Lodish, H., Berk, A., Matsudaira, P. et al 2004, Molecular Biology of the Cell. WH Freeman, New York, NY, ed.5 p963

5. Gardlík, R., Pálffy, R.,Hodosy, J., Lukács, J., Turna, J. and Celec, P. 2005, Vectors and delivery systems in gene therapy. Med Sci Monit., 11(4):RA110-21

6. Woods, N.-B, Bottero, V., Schmidt, M., von Kalle, C. \& Verma, I. M. 2006, Gene therapy: therapeutic gene causing lymphoma. Nature, 440, 1123

7. Okada, Y., Okada, N., Mizuguchi, H., Hayakawa, T., Mayumi, T.and Mizuno, N. 2003, An investigation of adverse effects caused by the injection of high-dose TNF -expressing adenovirus vector into established murine melanoma. Gene Therapy, 10, 700-705 
8. Douglas, J.T. 2007, Adenoviral vectors for gene therapy. Mol Biotechnol.,36, 71-80

9. Fildes, V. 1988, Wet Nursing: A History from Antiquity to the Present. Oxford, Basil Blackwell,

10. Gartner, L.M., Morton, J.and Lawrence, R.A.2005, .Breast feeding and the use of human milk. Pediatrics, 115, 496-506

11. Ramharter, M., Chai, S.K., Adegnika, A.A., et al. 2004, Shared breastfeeding in central Africa. AIDS, 18, 1847-1849

12. Claud, E.C. 2009, Neonatal Necrotizing Enterocolitis -Inflammation and Intestinal Immaturity. Antiinflamm Antiallergy Agents Med Chem., 8, 248-259

13. Cregan, M.D., Fan, Y., Appelbee, A., et al. 2007, Identification of nestin-positive putative mammary stem cells in human breastmilk.Cell Tissue Res., 329, 129-36

14. Elawdan,K.M.E. Personal DNA sequence modification: a potential new modality for gene transmission and therapy as well as mammalians evolution.18th congress of European society for gene and cell therapy ESGCT, Milan, Italy, 22- 25 Oct.2010.

15. Elawdan,K.M.E. Personal DNA sequence modification: a potential new modality for gene transmission and therapy as well as mammalians evolution. $10^{\text {th }}$ Asia-Pacific Conference on human genetics APCHG, Kuala Lumpur, Malaysia, 5-8 Dec. 2012.

16. van der Veen, R., Abrous, D.N., de Kloet, E.R., Piazza, P.V.and Koehl, M. 2008, Impact of intra- and interstrain cross-fostering on mouse maternal care. Genes Brain Behav., 7, 184-92

17. Singletary, K.B., Kloster, C.A.and Baker, D.G. 2003, Optimal age at fostering for derivation of Helicobacter hepaticus-free mice. Comp Med., 53(3):259-64

18. Leussis, M.P and Heinrichs, S.C. 2009, Quality of Rearing Guides Expression of Behavioral and Neural Seizure Phenotypes in El Mice. Brain Res., 1260, 84-93.

19. Hager, R., Cheverud, J.M. and Wolf, J.B. 2009, Change in maternal environment induced by crossfostering alters genetic and epigenetic effects on complex traits in mice. Proc Biol Sci., 276, 2949-54

20. Lu, L., Mamiya, T., Lu, P. et al. 2009, The long-lasting effects of cross-fostering on the emotional behavior in ICR mice. Behav Brain Res., 198, 172-8.

21. Ma, L.J., Walter, B., Deguzman, A., Muller, H.K and Walker, A.M. 2008 Trans-epithelial immune cell transfer during suckling modulates delayed-type hypersensitivity in recipients as a function of gender. PLoS One. , 3, e3562

\section{Tables}


Table no: 1

Genetic sharing of first baby $2^{\text {nd }}, 3$ rd and $4^{\text {th }}$ sample with $1^{\text {st }}$ sample

Kilo base (Kb), Million base (Mb), low DNA sharing (no copy match), medium DNA sharing (only one copy match) and high DNA sharing (two copy match)

\begin{tabular}{|c|c|c|c|c|c|c|c|c|c|}
\hline \multirow[b]{2}{*}{$\begin{array}{l}\text { Size of } \\
\text { fragment }\end{array}$} & \multicolumn{3}{|c|}{$\begin{array}{c}\text { First baby } 2 \text { nd sample } \\
\text { compared to } 1^{\text {st }} \text { sample }\end{array}$} & \multicolumn{3}{|c|}{$\begin{array}{c}\text { First baby 3rd sample } \\
\text { compared to } 1^{\text {st }} \text { sample }\end{array}$} & \multicolumn{3}{|c|}{$\begin{array}{c}\text { First baby 4th sample } \\
\text { compared to } 1^{\text {st }} \text { sample }\end{array}$} \\
\hline & $\begin{array}{l}\text { Low } \\
\text { DNA } \\
\text { sharing }\end{array}$ & $\begin{array}{l}\text { Medium } \\
\text { DNA } \\
\text { sharing }\end{array}$ & $\begin{array}{l}\text { High } \\
\text { DNA } \\
\text { sharing }\end{array}$ & $\begin{array}{l}\text { Low } \\
\text { DNA } \\
\text { sharing }\end{array}$ & $\begin{array}{l}\text { Medium } \\
\text { DNA } \\
\text { sharing }\end{array}$ & $\begin{array}{l}\text { High } \\
\text { DNA } \\
\text { sharing }\end{array}$ & $\begin{array}{l}\text { Low } \\
\text { DNA } \\
\text { sharing }\end{array}$ & $\begin{array}{l}\text { Medium } \\
\text { DNA } \\
\text { sharing }\end{array}$ & $\begin{array}{l}\text { High } \\
\text { DNA } \\
\text { sharing }\end{array}$ \\
\hline $250 \mathrm{~kb}$ & $0.0 \%$ & $0.2 \%$ & $99.8 \%$ & $0.0 \%$ & $0.0 \%$ & $100 \%$ & $0.0 \%$ & $0.0 \%$ & $100 \%$ \\
\hline $500 \mathrm{~kb}$ & $0.1 \%$ & $0.5 \%$ & $99.4 \%$ & $0.0 \%$ & $0.0 \%$ & $100 \%$ & $0.1 \%$ & $0.0 \%$ & $99.9 \%$ \\
\hline $1 \mathrm{Mb}$ & $0.2 \%$ & $1.6 \%$ & $98.2 \%$ & $0.0 \%$ & $0.0 \%$ & $100 \%$ & $0.2 \%$ & $0.1 \%$ & $99.7 \%$ \\
\hline $2 \mathrm{Mb}$ & $0.4 \%$ & $7.1 \%$ & $92.5 \%$ & $0.0 \%$ & $0.1 \%$ & $99.9 \%$ & $0.2 \%$ & $0.2 \%$ & $99.6 \%$ \\
\hline $3 \mathrm{Mb}$ & $0.0 \%$ & $0.2 \%$ & $99.8 \%$ & $0.0 \%$ & $0.0 \%$ & $100 \%$ & $0.0 \%$ & $0.0 \%$ & $100 \%$ \\
\hline $5 \mathrm{Mb}$ & $0.2 \%$ & $0.1 \%$ & $99.7 \%$ & $0.0 \%$ & $0.0 \%$ & $100 \%$ & $0.0 \%$ & $0.0 \%$ & $100 \%$ \\
\hline $10 \mathrm{Mb}$ & $1.4 \%$ & $0.5 \%$ & $98.1 \%$ & $0.0 \%$ & $0.0 \%$ & $100 \%$ & $0.2 \%$ & $0.0 \%$ & $99.8 \%$ \\
\hline $20 \mathrm{Mb}$ & $3.9 \%$ & $3.0 \%$ & $93.1 \%$ & $0.0 \%$ & $0.0 \%$ & $100 \%$ & $0.9 \%$ & $1.0 \%$ & $98.1 \%$ \\
\hline
\end{tabular}

Table no: 2

Genetic sharing of second baby $2^{\text {nd }}, 3$ rd and $4^{\text {th }}$ sample with $1^{\text {st }}$ sample

Kilo base (Kb), Million base (Mb), low DNA sharing (no copy match), medium DNA sharing (only one copy match) and high DNA sharing (two copy match) 


\begin{tabular}{|c|c|c|c|c|c|c|c|c|c|}
\hline \multirow[b]{2}{*}{$\begin{array}{l}\text { Size of } \\
\text { fragment }\end{array}$} & \multicolumn{3}{|c|}{$\begin{array}{l}\text { second baby } 2 \text { nd sample } \\
\text { compared to } 1^{\text {st }} \text { sample }\end{array}$} & \multicolumn{3}{|c|}{$\begin{array}{l}\text { second baby } 3 \text { rd sample } \\
\text { compared to } 1^{\text {st }} \text { sample }\end{array}$} & \multicolumn{3}{|c|}{$\begin{array}{l}\text { second baby } 4 \text { th sample } \\
\text { compared to } 1^{\text {st }} \text { sample }\end{array}$} \\
\hline & $\begin{array}{l}\text { Low } \\
\text { DNA } \\
\text { sharing }\end{array}$ & $\begin{array}{l}\text { Medium } \\
\text { DNA } \\
\text { sharing }\end{array}$ & $\begin{array}{l}\text { High } \\
\text { DNA } \\
\text { sharing }\end{array}$ & $\begin{array}{l}\text { Low } \\
\text { DNA } \\
\text { sharing }\end{array}$ & $\begin{array}{l}\text { Medium } \\
\text { DNA } \\
\text { sharing }\end{array}$ & $\begin{array}{l}\text { High } \\
\text { DNA } \\
\text { sharing }\end{array}$ & $\begin{array}{l}\text { Low } \\
\text { DNA } \\
\text { sharing }\end{array}$ & $\begin{array}{l}\text { Medium } \\
\text { DNA } \\
\text { sharing }\end{array}$ & $\begin{array}{l}\text { High } \\
\text { DNA } \\
\text { sharing }\end{array}$ \\
\hline $250 \mathrm{~kb}$ & $0.0 \%$ & $0.2 \%$ & $99.8 \%$ & $0.0 \%$ & $0.2 \%$ & $99.8 \%$ & $0.0 \%$ & $0.2 \%$ & $99.8 \%$ \\
\hline $500 \mathrm{~kb}$ & $0.0 \%$ & $0.7 \%$ & $99.3 \%$ & $0.0 \%$ & $0.4 \%$ & $99.6 \%$ & $0.1 \%$ & $0.5 \%$ & $99.4 \%$ \\
\hline $1 \mathrm{Mb}$ & $0.1 \%$ & $2.0 \%$ & $97.9 \%$ & $0.1 \%$ & $1.1 \%$ & $98.8 \%$ & $0.2 \%$ & $1.3 \%$ & $98.5 \%$ \\
\hline $2 \mathrm{Mb}$ & $0.5 \%$ & $6.7 \%$ & $92.8 \%$ & $0.3 \%$ & $3.4 \%$ & $96.3 \%$ & $0.8 \%$ & $5.1 \%$ & $94.1 \%$ \\
\hline $3 \mathrm{Mb}$ & $0.1 \%$ & $0.5 \%$ & $99.4 \%$ & $0.0 \%$ & $0.2 \%$ & $99.8 \%$ & $0.0 \%$ & $0.2 \%$ & $99.8 \%$ \\
\hline $5 \mathrm{Mb}$ & $0.4 \%$ & $0.7 \%$ & $98.9 \%$ & $0.2 \%$ & $0.2 \%$ & $99.6 \%$ & $0.2 \%$ & $0.4 \%$ & $99.4 \%$ \\
\hline $10 \mathrm{Mb}$ & $1.9 \%$ & $1.3 \%$ & $96.8 \%$ & $1.5 \%$ & $0.2 \%$ & $98.2 \%$ & $1.2 \%$ & $1.7 \%$ & $97.1 \%$ \\
\hline $20 \mathrm{Mb}$ & $4.2 \%$ & $5.1 \%$ & $90.7 \%$ & $0.7 \%$ & $3.2 \%$ & $96.1 \%$ & $1.7 \%$ & $4.0 \%$ & $94.3 \%$ \\
\hline
\end{tabular}

Table no: 3

Genetic sharing of third baby 3rd and $4^{\text {th }}$ sample with $1^{\text {st }}$ sample

Kilo base (Kb), Million base (Mb), low DNA sharing (no copy match), medium DNA sharing (only one copy match) and high DNA sharing (two copy match)

\begin{tabular}{|c|c|c|c|c|c|c|}
\hline & \multicolumn{3}{|c|}{$\begin{array}{c}\text { Third baby } 3 \text { rd sample compared to } 1^{\text {st }} \\
\text { sample }\end{array}$} & \multicolumn{3}{|c|}{$\begin{array}{c}\text { Third baby 4th sample compared to } 1^{\text {st }} \\
\text { sample }\end{array}$} \\
\hline $\begin{array}{l}\text { Size of } \\
\text { fragment }\end{array}$ & $\begin{array}{l}\text { Low DNA } \\
\text { sharing }\end{array}$ & $\begin{array}{l}\text { Medium DNA } \\
\text { sharing }\end{array}$ & $\begin{array}{l}\text { High DNA } \\
\text { sharing }\end{array}$ & $\begin{array}{l}\text { Low DNA } \\
\text { sharing }\end{array}$ & $\begin{array}{l}\text { Medium DNA } \\
\text { sharing }\end{array}$ & $\begin{array}{l}\text { High DNA } \\
\text { sharing }\end{array}$ \\
\hline $250 \mathrm{~kb}$ & $0.0 \%$ & $0.2 \%$ & $99.8 \%$ & $0.0 \%$ & $0.2 \%$ & $99.8 \%$ \\
\hline $500 \mathrm{~kb}$ & $0.0 \%$ & $0.7 \%$ & $99.3 \%$ & $0.1 \%$ & $0.6 \%$ & $99.3 \%$ \\
\hline $1 \mathrm{Mb}$ & $0.1 \%$ & $2.3 \%$ & $97.6 \%$ & $0,2 \%$ & $2.2 \%$ & $97.6 \%$ \\
\hline $2 \mathrm{Mb}$ & $0.5 \%$ & $7.4 \%$ & $92.1 \%$ & $0.9 \%$ & $6.4 \%$ & $92.7 \%$ \\
\hline $3 \mathrm{Mb}$ & $0.1 \%$ & $0.2 \%$ & $99.7 \%$ & $0.0 \%$ & $0.2 \%$ & $99.8 \%$ \\
\hline $5 \mathrm{Mb}$ & $0.4 \%$ & $0.2 \%$ & $99.4 \%$ & $0.2 \%$ & $0.2 \%$ & $99.6 \%$ \\
\hline $10 \mathrm{Mb}$ & $2.1 \%$ & $1.3 \%$ & $96.6 \%$ & $2.1 \%$ & $0.5 \%$ & $97.4 \%$ \\
\hline $20 \mathrm{Mb}$ & $4.7 \%$ & $8.5 \%$ & $86.8 \%$ & $5.9 \%$ & $4.7 \%$ & $89.4 \%$ \\
\hline
\end{tabular}

\section{Supplementary Files}

This is a list of supplementary files associated with this preprint. Click to download.

- supplementary2.doc 